\title{
Khasiat Proteksi Madu terhadap Kerusakan Hepar Tikus yang Diinduksi Etanol
}

\author{
Muhartono, Larasati N. D., Rizki Hanriko, Sutyarso \\ Bagian Biomedik Fakultas Kedokteran Universitas Lampung
}

\begin{abstract}
Abstrak
Madu merupakan salah satu produk lebah madu yang sering digunakan sebagai obat sejak zaman dahulu. Madu memiliki aktivitas antioksidan yang tinggi, namun penelitian untuk mengetahui efek protektifnya terhadap kerusakan hepar akibat etanol belum dilakukan di Indonesia. Penelitian ini bertujuan mengetahui efek protektif madu terhadap kerusakan hepar tikus yang diinduksi etanol. Penelitian ini dilaksanakan pada November 2011 di laboratorium Farmakologi dan Patologi Anatomi Fakultas Kedokteran Universitas Lampung. Penelitian eksperimental laboratorik ini menggunakan rancangan acak lengkap terhadap 25 ekor tikus yang dibagi menjadi lima kelompok. Kelompok 1: kontrol; kelompok 2: etanol; kelompok 3, 4, dan 5: madu + etanol. Etanol 0,01 mL/ gBB diberikan per oral kepada kelompok 2, 3, 4, dan 5 selama 14 hari. Kelompok madu + etanol diberi madu per oral dosis $0,0018 \mathrm{~mL} / \mathrm{gBB}, 0,0054 \mathrm{~mL} / \mathrm{gBB}$, dan $0,016 \mathrm{~mL} / \mathrm{gBB} 1,5$ jam sebelum pemberian etanol. Sampel hepar diambil untuk pemeriksaan histopatologi. Parameter kerusakan hepar berupa degenerasi lemak. Hasilnya menunjukkan etanol menyebabkan degenerasi lemak dibandingkan dengan kelompok kontrol. Kelompok 3, 4, dan 5 menunjukkan penurunan degenerasi lemak secara bermakna ( $<00,050 ; p<0,001 ; p<0,001)$. Perbaikan terlihat jelas pada kelompok 5. Simpulan, madu berefek protektif terhadap kerusakan hepar tikus. [MKB. 2013;45(1):1622]
\end{abstract}

Kata kunci: Degenerasi lemak, etanol, madu

\section{The Protective Effect of Honey on Ethanol-Induced Liver Injury in Rats}

\begin{abstract}
Honey is one of the honeybee's' products which are often used as medicine since a long time ago. Honey has a high antioxidant activity, but studies to investigate its protective effect on ethanol-induced liver injury have not been carried out in Indonesia. The aim of this study was to investigate the protective effect of honey on ethanol-induced rat liver injury. This study done conducted in the Pharmacology and Pathology laboratory in November 2011. This experimental laboratory study used randomized complete design on 25 rats divided into five groups. Group 1: control; group 2: ethanol; group 3, 4 and 5: honey + ethanol. Ethanol $0.01 \mathrm{~mL} / \mathrm{g}$ body weight was given orally to group 2, 3, 4 and 5 for 14 days. Honey + ethanol groups were given honey at a dose of $0.0018 \mathrm{~mL} / \mathrm{g}$ body weight, $0.0054 \mathrm{~mL} / \mathrm{g}$ body weight, and $0.016 \mathrm{~mL} / \mathrm{g}$ body weight orally at 1.5 hours prior to ethanol administration. Liver samples were taken for histopathological examination. The parameter of liver injury was fatty degeneration. The results showed that ethanol induced fatty degeneration compared to control group. Group 3, 4 and 5 showed significantly decreased fatty degeneration $(p<0.050, p<0.001, p<0.001)$. The improvement was prominent in group 5. In conclusion, honey has a protective effect on rat liver injury. [MKB. 2013;45(1):16-22]
\end{abstract}

Key words: Ethanol, fatty degeneration, honey

Korespondensi: Muhartono, dr., M.Kes. Sp.PA, Fakultas Kedokteran Universitas Lampung, jalan Soemantri Brojonegoro No.1 Bandar Lampung, mobile 081272358340, e-mail dmuhartono@yahoo.com 


\section{Pendahuluan}

Akhir-akhir ini, dalam kehidupan zaman modern penanggulangan penyakit mulai beranjak kembali pada penggunaan obat-obatan tradisional. ${ }^{1}$ World Health Organization (WHO) merekomendasikan penggunaan obat-obatan tradisional dalam upaya pencegahan dan pengobatan penyakit, terutama penyakit kronik dan penyakit degeneratif. ${ }^{2}$

Salah satu obat tradisional yang sudah dikenal di peradaban seluruh dunia adalah madu. Madu merupakan cairan manis dari nektar tumbuhan yang diproduksi oleh lebah madu. Sejak 3.500 tahun lalu, orang Mesir kuno telah menggunakan madu untuk mengobati luka. ${ }^{3}$ Madu mengandung $80 \%$ karbohidrat, $20 \%$ air, termasuk beberapa protein. Madu telah terbukti memiliki aktivitas antioksidan oleh karena kandungan flavonoidnya tinggi. ${ }^{4}$ Antioksidan lain dalam madu yaitu asam amino, protein, dan fitokimia golongan polifenol. Di samping itu, madu juga mengandung beberapa enzim, yaitu glukosa oksidase dan katalase, serta beberapa vitamin, yaitu vitamin A, B kompleks, C, E, dan betakaroten ${ }^{4,5}$

Salah satu oksidan yang dapat menimbulkan stres oksidatif adalah etanol. Etanol dipilih sebagai oksidan mengingat penyalahgunaan etanol telah menjadi permasalahan sosial di seluruh dunia. ${ }^{6}$ Konsumsi etanol telah lama dihubungkan dengan penyakit hepar. Hepar merupakan tempat utama metabolisme etanol sehingga menderita kerusakan yang paling parah akibat konsumsi etanol. Hal ini disebabkan etanol dapat meningkatkan produksi reactive oxygen species (ROS) dan menurunkan kadar antioksidan selular. ${ }^{7}$

Beberapa penelitian telah dilakukan untuk menguji kandungan antioksidan madu sehingga berefek hepatoprotektif. Pemberian madu per oral pada tikus Sprague Dawley jantan yang diinduksi $\mathrm{CCl}_{4}$ akan mampu memperbaiki secara bermakna gambaran histopatologi hepar serta ginjal tikus karena kandungan antioksidan yang terdapat dalam madu. ${ }^{8}$ Dewi ${ }^{9}$ memberikan madu dengan dosis $0,078 \mathrm{~mL} / 20 \mathrm{gBB}$ kepada mencit, yang setara dengan $30 \mathrm{~mL}$ untuk manusia, selama 14 hari berturut-turut dan madu tersebut dapat mengurangi kerusakan sel hepar mencit akibat natrium siklamat secara signifikan.

Madu mempunyai potensi yang sangat besar sebagai antioksidan, tetapi konsumsi madu di Indonesia masih rendah, yaitu $15 \mathrm{~g} /$ orang/tahun. Keadaan ini sangat berbeda dengan negara maju, seperti Jerman Barat dan Swiss yang setiap tahun mengonsumsi madu sebanyak $800 \mathrm{~g}-1,4 \mathrm{~kg} /$ orang, Australia mengonsumsi madu 600 g/orang/ tahun, dan Jepang mengonsumsi madu sekitar 200 hingga $300 \mathrm{~g} /$ orang/tahun. ${ }^{3}$ Mengingat fakta tersebut dan berdasarkan penelitian tentang madu sebagai hepatoprotektor kerusakan akibat etanol masih jarang dilakukan di Indonesia, oleh karena itu dilakukan penelitian untuk mengetahui efek protektif madu terhadap kerusakan hepar tikus jantan yang diinduksi dengan etanol.

\section{Metode}

Penelitian ini merupakan penelitian eksperimental laboratorik mempergunakan metode rancangan acak terkontrol dengan pola post test only control group design. Sebanyak 25 ekor tikus putih (Rattus norvegicus) jantan dewasa galur Sprague Dawley berumur 3-4 bulan yang dipilih secara acak yang dibagi menjadi lima kelompok, dengan pengulangan sebanyak lima kali, sesuai dengan rumus Frederer $t(n-1)>15$, dinyatakan dengan huruf t. Jumlah kelompok percobaan dan $\mathrm{n}$ merupakan jumlah pengulangan atau jumlah sampel setiap kelompok. Penelitian dilakukan di Laboratorium Farmakologi dan Patologi Anatomi Fakultas Kedokteran Universitas Lampung bulan November 2011. Tikus putih didapat dari Fakultas Peternakan Institut Pertanian Bogor.

Kerusakan hepartikus diinduksimenggunakan etanol. Pemberian etanol 50\% (v/v) dengan dosis $5 \mathrm{~g} / \mathrm{kgBB}$ per oral kepada tikus selama 10 hari dapat menyebabkan sel hepar tikus mengalami nekrosis, fibrosis, dan infiltrasi sel inflamasi. ${ }^{6} \mathrm{Jika}$ konsentrasi etanol yang diinginkan $50 \%$, maka dalam $50 \% \mathrm{v} / \mathrm{v} 100 \mathrm{~mL}$ terdapat 50 gram etanol sehingga dosis volume etanol yang diberikan sebanyak $10 \mathrm{~mL} / \mathrm{kgBB}$. Etanol diberikan 1,5 jam setelah pemberian madu.

Dosis madu yang diberikan $0,0027 \mathrm{~mL} / \mathrm{gBB}$ sudah terbukti mampu melindungi hepar mencit yang diinduksi oleh natrium siklamat selama 14 hari. ${ }^{9}$ Dosis madu pertama dan ketiga ditentukan berdasarkan standar pengobatan herbal Asean, yaitu dosis paling rendah $1 / 3$ kali dosis dan dosis paling tinggi 3 kali dosis. ${ }^{10}$ Madu yang diberikan pada tikus merupakan larutan madu 50\% yang diencerkan dengan akuades.

Tikus sebanyak 25 ekor dibagi dalam lima kelompok. Kelompok I (K1) sebagai kontrol normal (negatif) hanya diberi akuades. Kelompok II (K2) sebagai kontrol patologis (positif) diberi etanol 50\% 0,01 mL/gBB. Kelompok III (K3) adalah kelompok perlakuan dengan pemberian etanol 50\% 0,01 mL/gBB ditambah larutan madu $50 \%$ dosis $0,0018 \mathrm{~mL} / \mathrm{gBB}$, kelompok IV (K4) dengan dosis larutan madu 50\% sebanyak 0,0054 $\mathrm{mL} / \mathrm{gBB}$, serta kelompok $\mathrm{V}$ (K5) dengan dosis larutan madu 50\% sebanyak 0,016 mL/gBB, larutan madu dan etanol 50\% tersebut diberikan $1 \mathrm{kali} /$ hari. Masing-masing diberikan secara per oral selama 14 hari. Selama satu minggu setiap 
kelompok tikus diadaptasikan sebelum dilakukan perlakuan. Setelah 14 hari, dilakukan narkosis menggunakan kloroform, dilakukan laparatomi, setelah itu diambil hepar masing-masing tikus untuk dibuat 1 (satu) preparat. Sampel hepar difiksasi dengan larutan formalin 10\%, kemudian pembuatan preparat dilakukan dengan metode parafin dan juga pewarnaan HE (hematoksilineosin). Parameter kerusakan hepar tikus yang terjadi berupa degenerasi lemak diamati dengan mikroskop perbesaran 400 kali. Skala degenerasi lemak kemudian dihitung secara semikuantitatif dalam 5 lapang pandang berbeda dengan kriteria penilaian adalah skor $0=$ tidak terdapat hepatosit yang mengalami degenerasi lemak; skor $1=<10 \%$ hepatosit yang mengalami degenerasi lemak; skor $2=10-33 \%$ hepatosit mengalami degenerasi lemak; skor 3=34-66\% hepatosit yang mengalami degenerasi lemak; skor $4=>66-100 \%$ hepatosit yang mengalami degenerasi lemak. ${ }^{11}$ Data diuji dengan one way ANOVA dan post-hoc LSD. Hipotesis bermakna bila $\mathrm{p}<0,050$.

\section{Hasil}

Hasil penelitian berupa preparat histopatologis hepar tikus diperiksa mikroskopik menggunakan mikroskop cahaya dengan pembesaran 1.000x untuk menganalisis degenerasi lemak yang telah terjadi. Setiap preparat hepar diambil lima lapang pandang untuk ditentukan skor degenerasi lemak pada masing-masing lapang pandang kemudian dihitung persentase skor degenerasi lemak ratarata.

Dari hasil analisis mikroskopik gambaran degenerasi lemak hepatosit tikus, didapat hasil skor degenerasi lemak rata-rata dari setiap lapang pandang yang dihitung pada kelompok kontrol normal K1 yaitu 5,0 $\pm 3,54$; kelompok kontrol patologis yaitu $\mathrm{K} 2$ sebesar 40,0 $\pm 3,54$; kelompok perlakuan K3 dengan dosis $0,0018 \mathrm{~mL} / \mathrm{gBB}$ sebesar 30,0 $\pm 5,00$; pada kelompok perlakuan $\mathrm{K} 4$ dengan dosis $0,0054 \mathrm{~mL} / \mathrm{gBB}$ sebesar 18,0 $\pm 5,70$; dan kelompok perlakuan K5 dengan dosis 0,016 $\mathrm{mL} / \mathrm{gBB}$ sebesar $6,0 \pm 4,18$. Hasil persentase ratarata skor sel yang mengalami degenerasi lemak

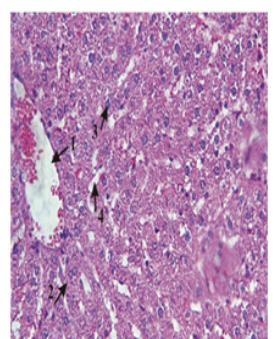

a

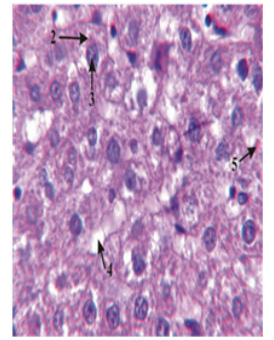

$\mathrm{f}$

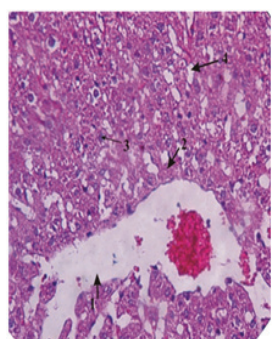

b

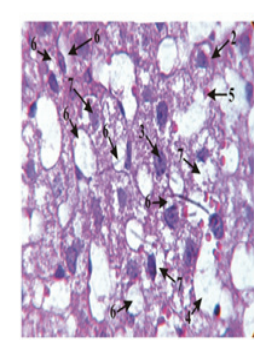

g

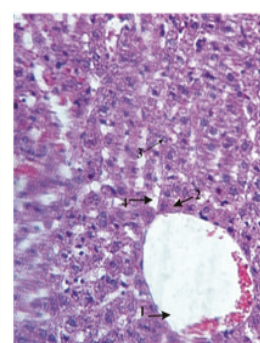

C

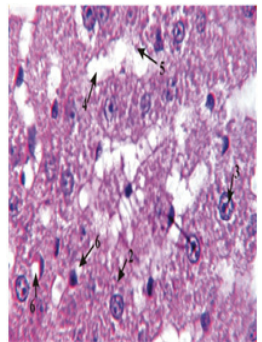

h

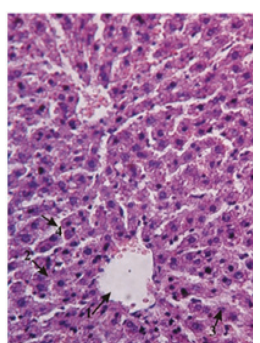

d

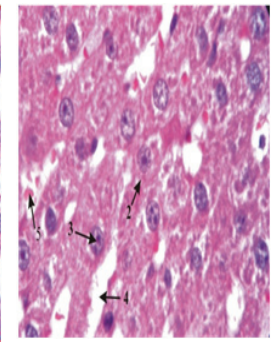

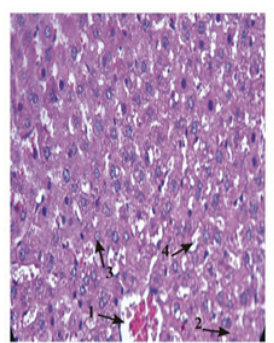

e

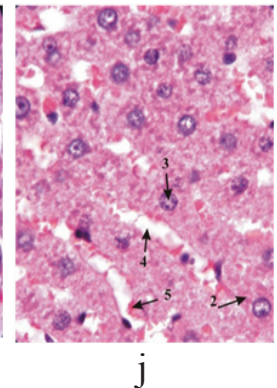

Gambar 1 Histopatologi Kelompok Perlakuan dengan Pembesaran 400x, K1 (a), K2 (b), K3 (c), K4 (d), K5 (e) dan Histopatologi Kelompok Perlakuan dengan Pembesaran 1.000x: K1 (f), K2 (g), K3 (h), K4 (i), K5 (j). Kelompok K2 Terdapat Degenerasi Lemak Paling Banyak setelah Diberikan Etanol; K3, K4 dan K5 Terjadi Penurunan Degenerasi Lemak Signifikan setelah Diberikan Madu Sebelum Diberikan Etanol 
Tabel 1 Persentase Skor Degenerasi Lemak Rata-rata Hepar Tikus

\begin{tabular}{|c|c|c|c|c|c|c|c|c|}
\hline \multirow{2}{*}{\multicolumn{2}{|c|}{ Kelompok }} & \multicolumn{5}{|c|}{ Skor } & \multirow{2}{*}{$\begin{array}{l}\text { Total } \\
\text { Skor }\end{array}$} & \multirow{2}{*}{$\begin{array}{c}\text { Rata-Rata } \\
(\%)^{*}\end{array}$} \\
\hline & & LP1 & LP2 & LP3 & LP4 & LP5 & & \\
\hline \multicolumn{9}{|l|}{ K1 } \\
\hline & 1 & 0 & 1 & 0 & 0 & 0 & 1 & 5,0 \\
\hline & 2 & 1 & 0 & 0 & 0 & 0 & 1 & 5,0 \\
\hline & 3 & 0 & 0 & 0 & 1 & 1 & 2 & 10,0 \\
\hline & 4 & 0 & 0 & 0 & 0 & 0 & 0 & 0,0 \\
\hline & 5 & 0 & 0 & 0 & 0 & 1 & 1 & 5,0 \\
\hline \multicolumn{9}{|l|}{$\mathrm{K} 2$} \\
\hline & 1 & 2 & 1 & 1 & 2 & 2 & 8 & 40,0 \\
\hline & 2 & 2 & 1 & 2 & 1 & 1 & 7 & 35,0 \\
\hline & 3 & 2 & 2 & 2 & 2 & 1 & 9 & 45,0 \\
\hline & 4 & 2 & 1 & 2 & 2 & 1 & & 40,0 \\
\hline & 5 & 1 & 1 & 2 & 2 & 2 & 8 & 40,0 \\
\hline \multicolumn{9}{|l|}{ K3 } \\
\hline & 1 & 1 & 1 & 1 & 2 & 1 & 6 & 30,0 \\
\hline & 2 & 1 & 2 & 1 & 2 & 1 & 7 & 35,0 \\
\hline & 3 & 1 & 2 & 1 & 1 & 0 & 5 & 25,0 \\
\hline & 4 & 2 & 1 & 1 & 1 & 2 & 7 & 35,0 \\
\hline & 5 & 0 & 1 & 2 & 1 & 1 & 5 & 25,0 \\
\hline \multicolumn{9}{|l|}{ K4 } \\
\hline & 1 & 1 & 1 & 0 & 1 & 1 & 4 & 20,0 \\
\hline & 2 & 1 & 1 & 0 & 0 & 0 & 2 & 10,0 \\
\hline & 3 & 1 & 1 & 1 & 0 & 1 & 4 & 20,0 \\
\hline & 4 & 1 & 1 & 1 & 1 & 1 & 5 & 25,0 \\
\hline & 5 & 1 & 0 & 1 & 0 & 1 & 3 & 15,0 \\
\hline \multicolumn{9}{|l|}{ K5 } \\
\hline & 1 & 0 & 1 & 0 & 1 & 0 & 2 & 10,0 \\
\hline & 2 & 0 & 0 & 1 & 0 & 0 & 1 & 5,0 \\
\hline & 3 & 1 & 1 & 0 & 0 & 0 & 2 & 10,0 \\
\hline & 4 & 0 & 0 & 0 & 0 & 0 & 0 & 0,0 \\
\hline & 5 & 0 & 0 & 0 & 0 & 1 & 1 & 5,0 \\
\hline
\end{tabular}

Keterangan: $\mathrm{LP}(1-5)=$ lapang pandang, $\mathrm{K}(1-5)=$ kelompok tikus, *=Total skor/20x100\%

pada hepar tikus kemudian dianalisis kenormalan distribusi datanya dengan mempergunakan Uji Normalitas Shapiro-Wilk. Semua kelompok uji memiliki distribusi data yang normal karena memiliki nilai $\mathrm{p}>0,050$ (Tabel 3). Selanjutnya, hasil persentase skor sel rata-rata yang mengalami degenerasi lemak dianalisis dengan uji Levene untuk mengetahui apakah dua atau lebih kelompok uji memiliki varians data yang homogen atau tidak. Hasil Uji Levene didapatkan nilai $\mathrm{p}>0,050$ sehingga disimpulkan data memiliki varians yang homogen.

Data memiliki distribusi normal dan homogen, maka selanjutnya data dianalisis menggunakan uji parametrik one way ANOVA dan didapatkan nilai $\mathrm{p}<0,001$ yang berarti paling tidak terdapat dua kelompok yang mempunyai perbedaan ratarata yang bermakna. Untuk mengetahui kelompok 
Tabel 2 Hasil Gambaran Degenerasi Lemak Rata-rata pada Kelompok Uji

\begin{tabular}{cc}
\hline Kelompok & $\begin{array}{c}\text { Degenerasi Lemak Rata-rata } \\
(\mathbf{X} \pm \mathbf{S D})\end{array}$ \\
\hline K1 & $5,0 \pm 3,54$ \\
K2 & $40,0 \pm 3,54$ \\
K3 & $30,0 \pm 5,00$ \\
K4 & $18,0 \pm 5,70$ \\
K5 & $6,0 \pm 4,18$ \\
\hline
\end{tabular}

mana yang berbeda secara bermakna, dilakukan analisis Post-Hoc LSD.

Dari analisis Post-Hoc LSD didapat hasil berupa perbedaan gambaran degenerasi lemak yang bermakna kelompok kontrol normal K1 dengan semua kelompok uji yang lain, yaitu K1 dengan K2 memiliki $\mathrm{p}<0,001$; K1 dengan K3 memiliki $\mathrm{p}<0,001$; $\mathrm{K} 1$ dengan $\mathrm{K} 4$ memiliki nilai $\mathrm{p}<0,001$; kecuali antara K1 dengan K5 memiliki perbedaan yang tidak bermakna dengan nilai $p>0,050$. Perbedaan gambaran degenerasi lemak yang bermakna juga terdapat pada kelompok kontrol patologis $\mathrm{K} 2$ dan $\mathrm{K} 3$ dengan $\mathrm{p}<0,050$; $\mathrm{K} 2$ dan $\mathrm{K} 4$ dengan $\mathrm{p}<0,001 ; \mathrm{K} 2$ dan K5 dengan $\mathrm{p}<0,001$; serta pada kelompok perlakuan madu $\mathrm{K} 3$ dan $\mathrm{K} 4$ dengan $\mathrm{p}<0,001$; $\mathrm{K} 3$ dan $\mathrm{K} 5$ dengan $p<0,001 ;$ dan $K 4$ dan $K 5$ dengan $p<0,001$.

\section{Pembahasan}

Gambaran degenerasi lemak yang terjadi pada kelompok kontrol patologis K2 berbeda bermakna daripada semua kelompok uji karena kelompok ini hanya diberi etanol sebagai zat oksidan yang dapat merusak, sedangkan K1 tidak diberi etanol, serta K3, K4 dan K5 diberikan madu sebagai hepatoprotektor.

Masing-masing kelompok perlakuan madu, yaitu K3, K4 dan K5, menunjukkan perbedaan degenerasi lemak yang bermakna. Keadaan ini

Tabel 3 Analisis Shapiro-Wilk Gambaran Degenerasi Lemak

\begin{tabular}{cc}
\hline Kelompok & $\mathbf{p}$ \\
\hline K1 & 0,325 \\
K2 & 0,325 \\
K3 & 0,119 \\
K4 & 0,814 \\
K5 & 0,314 \\
\hline
\end{tabular}

Tabel 4 Analisis Post-Hoc LSD Gambaran Degenerasi Lemak antar Kelompok

\begin{tabular}{ccl}
\hline \multicolumn{2}{c}{ Kelompok } & \multicolumn{1}{c}{ p } \\
\hline K1 & K2 & $0,000^{*}$ \\
& K3 & $0,000^{*}$ \\
& K4 & $0,000^{*}$ \\
K2 & K5 & 0,727 \\
& K3 & $0,002^{* *}$ \\
& K4 & $0,000^{*}$ \\
K3 & K5 & $0,000^{*}$ \\
& K4 & $0.000^{*}$ \\
K4 & K5 & $0,000^{*}$ \\
Keterangan: ${ }^{*}=\mathbf{p}<0,001 ; * *=p<0,050$ & $0,000^{*}$ \\
\hline
\end{tabular}

menandakan bahwa dosis madu yang dipakai cukup bervariasi sehingga mampu menghasilkan efek yang bervariasi pula. Kelompok perlakuan madu K3 sudah mulai memperlihatkan perbaikan gambaran histopatologi hepar bila dibandingkan dengan kelompok K2 dan didapatkan penurunan persentase skor degenerasi lemak rata-rata yang bermakna bila dibandingkan dengan K2, yakni menjadi 30\%. Penurunan ini masih kurang besar jika dibandingkan dengan kelompok $\mathrm{K} 4$ yang diberikan madu $50 \%$ dengan dosis $0,0054 \mathrm{~mL} / \mathrm{gBB}$ yang berhasil menurunkan persentase degenerasi lemak menjadi 18\%. Efek hepatoprotektif madu paling besar terlihat pada kelompok K5 yang diberikan madu $50 \%$ dosis $0,016 \mathrm{~mL} / \mathrm{gBB}$ yang berhasil untuk menurunkan persentase degenerasi lemak menjadi $6 \%$. Persentase degenerasi lemak kelompok ini hampir sama dengan persentase degenerasi lemak kelompok kontrol normal K1 sehingga tidak memberikan perbedaan bermakna pada uji Post-Hoc LSD.

Kelompok K3 telah menurunkan persentase skor degenerasi lemak rata-rata yang bermakna dibandingkan dengan $\mathrm{K} 2$, namun masih kurang besar pengaruhnya, K3 merupakan dosis paling rendah. Hasil ini sejalan dengan hasil penelitian Dewi ${ }^{9}$ yang mempergunakan madu dosis paling rendah, yaitu sebanyak $0,2 \mathrm{~mL} / 20 \mathrm{gBB}$ kepada mencit untuk melawan efek buruk dari natrium siklamat dan ternyata efek hepatoprotektif madu belum terlihat.

Kelompok K4 memperlihatkan penurunan persentase skor degenerasi lemak rata-rata yang lebih besar bila dibandingkan dengan K3 karena dosis madu yang dipergunakan pada kelompok ini adalah dosis madu yang sudah terbukti sebagai hepatoprotektor terhadap kerusakan sel-sel hepar mencit akibat natrium siklamat. ${ }^{9}$ Kelompok K5 
memberikan efek hepatoprotektif paling besar karena kelompok ini diberikan madu dosis paling tinggi.

Pemberian madu $50 \mathrm{mg} / \mathrm{kg}$ per oral pada tikus Sprague Dawley jantan yang diinduksi $\mathrm{CCl}_{4}$ juga mampu memperbaiki secara signifikan gambaran histopatologi hepar dan ginjal tikus oleh karena kandungan antioksidan yang terdapat di dalam madu. ${ }^{8}$ Pada penelitian lain, pemberian madu per oral dengan dosis $0,275 \mathrm{~g} / \mathrm{kg}$ satu jam sebelum suntikan $\mathrm{N}$-ethylmaleimide (NEM) kepada tikus putih Wistar menunjukkan perbaikan gambaran histopatologi hepar apabila dibandingkan dengan kelompok tikus yang tidak diberi madu. ${ }^{12}$ Mahesh dkk. ${ }^{13}$ juga sudah membuktikan efek madu india untuk memperbaiki kerusakan hepar tikus yang diinduksi stres oksidatif dari asetaminofen.

Gambaran histopatologis hepar kelompok K3, K4, dan K5 ini berkaitan dengan besarnya kandungan antioksidan di dalam madu. Contoh kandungan zat antioksidan madu yaitu vitamin $\mathrm{C}$, asam amino, dan protein. ${ }^{5}$ Madu juga mengandung berbagai jenis flavonoid, yaitu caffeic acid (CA), caffeic acid phenyl esters (CAPE), chrysin (CH), galangin (GA), quercetin (QU), kaempferol (KP), acacetin (AC), pinocembrin (PC), pinobanksin (PB), dan apigenin (AP). Kandungan antioksidan madu yang lain berupa enzim, seperti glukosa, oksidase dan katalase, vitamin A, B kompleks, E, dan betakaroten. ${ }^{4,5}$

Flavonoid memiliki peran untuk menangkap radikal bebas, seperti anion superoksida, radikal peroksil, hidroksil, serta radikal alkohoksil yang efektif. ${ }^{14-16}$ Flavonoid juga memiliki kemampuan untuk berikatan dengan ion logam, seperti besi dan tembaga yang dapat mengkatalisis produksi radikal bebas ${ }^{17}$ dan juga mengkatalisis peroksidasi lipid. ${ }^{18}$ Selain itu, flavonoid memiliki kemampuan memodulasi jalur sinyal sel yang dapat mengatur berbagai proses sel, misalnya pada pertumbuhan, proliferasi, dan apoptosis. ${ }^{19}$ Selain itu, mekanisme lain yang berperan di dalam aktivitas antioksidan flavonoid adalah inhibisi enzim-enzim oksidan atau produksi radikal bebas oleh sel, regenerasi $\alpha$-tokoferol dari radikal $\alpha$-tokoferoksil, dan dapat mengurangi peroksidasi lemak dan nitrit oksida. ${ }^{5}$

Keterbatasan penelitian ini tidak dilakukan pemeriksaan hepar sebelum perlakuan, sehingga terdapat kemungkinan saat tikus diambil sebagai sampel, sebelumnya sudah mengalami kerusakan hepar. Keadaan ini terlihat pada kelompok kontrol normal dengan ditemukan gambaran degenerasi lemak.

Simpulan, madu mempunyai efek protektif terhadap kerusakan hepar tikus putih (Rattus norvegicus) jantan dewasa galur Sprague Dawley yang diinduksi etanol.

\section{Daftar Pustaka}

1. Murti TK, Poerba AP. 101 ramuan tradisional untuk mengatasi berbagai penyakit. Yogyakarta: Insan Madani; 2010.

2. WHO. Traditional medicine. 2008 [diunduh 3 Oktober 2011]. Tersedia dari: http://www. who-int/mediacentre/factsheets/fs134/en/ index.html.

3. Aden R. Manfaat dan khasiat madu. Yogyakarta: Hanggar Kreator; 2010.

4. Mabrouk GM, Zohny SF, Ali EMM, Ismail EF, Moselhy SS. Bee honey and Nigella sativa inhibit nitric oxide mediated cytochrome $\mathrm{C}$ release and down-regulation of connexin 43 induced by methylnitrosurea in hepatic tissues of Sprague Dawley rats. Egypt J Biochem Mol Biol. 2004;22(2):73-86.

5. Yang C, Zeisberg M, Mosterman B, Sudhahar A, Yerramalla U, Holtihaus K. Liver fibrosis: insights into migration of hepatic stellate cells in response to extracellular matrix and growth factors. Gastroenterology. 2003;124(1):147-59.

6. Chen X. Protective effects of quercetin on liver injury induced by ethanol. Pharmacogn Mag. 2010;6(22):135-41.

7. Ha H, Shin HJ, Feitelson MA, Yu DY. Oxidative stress and antioxidants in hepatic pathogenesis. World J Gastroenterol. 2010;16(48):6035-43.

8. El Denshary ES, Al-Gahazali MA, Mannaa FA, Salem HA, Hassan NS, Abdel-Wahab MA. Dietary honey and ginseng protect against carbon tetrachloride-induced hepatonephrotoxicity in rats. Exp Toxicol Pathol. 2012;64(7-8):753-60.

9. Dewi MR. Pengaruh hepatoprotektor madu terhadap kerusakan histologis sel hepar mencit (Mus musculus) yang diberi perlakuan natrium siklamat [Skripsi]. Surakarta: Universitas Sebelas Maret Surakarta; 2010.

10. SSI. Standard of ASEAN herbal medicine. Edisi ke-2. Jakarta: ASEAN Countries; 2006.

11. Kawasaki T, Igarashi K, Koeda T, Sugimoto K, Nakagawa K, Hayashi S, dkk. Rats fed fructose-enriched diets have characteristics of nonalcoholic hepatic steatosis. J Nutr. 2009;139(11):2067-71.

12. Korkmaz A, Kolankaya D. Anzer honey prevents N-ethylmaleimide-induced liver damage in rats. Exp Toxicol Pathol. 2009;61(4):333-7.

13. Mahesh A, Shaheetha J, Thangadurai D, Rao DM. Protective effect of Indian honey on acetaminophen induced oxidative stress and liver toxicity in rat. Biologia. 
2009;64(6):1225-31.

14. Repetto MG, Llesuy SF. Antioxidant properties of natural compounds used in popular medicine for gastric ulcer. Braz J Med Biol Res. 2002;35(5):523-34.

15. Fiorani M, Accorsi A, Blasa M, Diamantini G, Piatti E. Flavonoids from Italian multifloral honey reduce the extracellular ferricyanide in human red blood cells. J Agric Food Chemistry. 2006;54(21):8328-34.

16. Chun OK, Kim DO, Lee CY. Superoxide radical scavenging activity of the major polyphenols in fresh plums. J Agric Food Chem. 2003;51(27):8067-72.
17. Mira L, Fernandez MT, Santos M, Rocha R, Florencio $\mathrm{MH}$, Jennings KR. Interactions of flavonoids with iron and copper ions: a mechanism for their antioxidant activity. Free Radic Res. 2002;36(11):1199-208.

18. Schroeter H, Boyd C, Spencer JP, Williams RJ, Cadenas E, Rice-Evans C. MAPK signaling in neurodegeneration: influences of flavonoids and of nitric oxide. Neurobiol Aging. 2002;23(5):861-80.

19. Williams RJ, Spencer JP, Rice-Evans C. Flavonoids: antioxidants or signalling molecules? Free Radic Biol Med. 2004;36(7):838-49. 